\title{
Farmer's perception on the role of babinsa in program of upsus pajale
}

\author{
Bekti Tri Astuti ${ }^{1}$, Arip Wijianto ${ }^{1}$, and Eksa Rusdiana $^{1}$ \\ ${ }^{1}$ Department of Agriculture Extension and Communication, Faculty of Agriculture, Universitas \\ Sebelas Maret, Surakarta, Indonesia
}

\begin{abstract}
This research aimed to analyze farmer's perception on the role of village supervisory non-commissioned officers (Babinsa) in the implementation of special effort program for improving rice, corn and soybean production (Upsus Pajale), to analyze the factors affecting farmer's perception on the role of Babinsa in the implementation of special effort program for improving rice, corn and soybean production (Upsus Pajale), and to analyze the relationship between factor affecting farmer's perception and farmer's perception on the role of Babinsa in the implementation of special effort program for improving rice, corn and soybean production (Upsus Pajale). The research took place in Sukoharjo regency because Sukoharjo Regency has implemented the Upsus Pajale program and has collaborated with Babinsa for facilitation in each village. The sampling technique used was simple random sampling. The data analysis was carried out using Spearman's rank correlational test. The result of research showed that farmer's perception on the role of Babinsa as motivator, facilitator, and supervisor belongs to moderate or neutral category; the factors affecting farmer's perception are need, mentality and emotionality, closeness, and cultural background, all of which affect significantly farmers' perceptions on the role of Babinsa in the implementation of Upsus Pajale.
\end{abstract}

\section{Introduction}

Food self-sufficiency condition in Indonesia lowers, leading this state to be on serious level in global starvation index, so that there will be predictably a serious food scarcity in the future [1]. Dealing with such condition, the government performs a process toward improvement with special effort (Indonesian: upaya khusus, thereafter called Upsus). One of special efforts (upaya khusus) of food self-sufficiency taken in Indonesia is upaya khusus padi, jagung, and kedelai (special effort for improving rice, corn and soybean production, thereafter called Upsus Pajale). It is because the three commodities are basic food material consumed widely by the community. Rice, corn, and soybean commodities are basic commodity that should be cultivated in order to fulfill the community's life needs [2]. Upsus Pajale has been promoted since 2015 and governed in Republic of Indonesia Ministry of Agriculture's Regulation Number 14 of 2015 about the guidelines of Integrated Guidance and Facilitation in the attempt of improving corn, rice, and soybean production, in which it will be facilitated by agricultural extension officer, university (students and lecturers), and Indonesian Army (TNI-AD) particularly village supervisory noncommissioned officers (Babinsa). 
Ministry of Agriculture cooperates with Indonesian Army (TNI) in the attempt of supporting food self-sufficiency special effort in 2017 including special effort program for Upsus Pajale. It is in line Wahyudin (2013) arguing that the existence of Babinsa in agricultural sector can be attempted to help solve the farmers' problem in Upsus Pajale program [3]. MoU between Republic of Indonesia's Ministry of Agriculture and TNI was signed on January 2015. After the enactment of MoU, the Army Chief of Staff (KASAD) assigned the village supervisory non-commissioned officers (Babinsa) to guide Upsus Pajale program [4]. Babinsa should have adequate ability that can spur his villagers to participate actively in development. Therefore, Babinsa is required to have mental condition and tough motivation (high struggle value), adequate professionalism, and reliable competency, including in agricultural sector, i.e. doing building and extension program in farming, fishery, animal husbandry, and etc and extension about Family Planning program. The role of Babinsa in guarding this Upsus Pajale program is similar to and can be said as temporary substitute for Field Agricultural Extension Officer (PPL) because of limited number of PPL today. The role of agricultural extension officer, according to [5], is to help the farmers develop healthy opinion and make good decision by means of communicating with and giving information the farmers need; in addition, agricultural extension officer can also help the farmers improve their farming.

Sukoharjo is one of regencies in Central Java Province having implemented Upsus Pajale program and has cooperated with Babinsa in facilitating individual villages. The programs having been conducted are, among others: constructing food warehouse with 100ton capacity, controlling farmland conversion, creating new farmland, intensifying farming system, and applying agricultural technology that can improve productivity and maintain environment quality all at once. Sukoharjo consisted of 12 sub districts, in which Weru sub district is the one conducting Upsus Pajale program completely with three commodities: rice, corn, and soybean.

The successful Upsus Pajale program is closely related to the role of Babinsa in performing its duty. Role, according to Soerjono Soekanto (2002), is a dynamic aspect of position (status); therefore, when an individual implements his/her right and obligation according to his/her position, it can be called undertaking a role. The quality of Babinsa's role can be seen from the farmers' perception. Perception, according to Sugihartono (2007), is the five senses' ability of translating stimuli; it can also be called a process of translating stimuli coming into human's senses. Human perception is divided into two perspectives: sensing perceiving something good or known as positive perception and sensing perceiving something not good or called negative perception. Both perceptions can affect human action visibly or really [6]. The quality of Babinsa's role can be seen from the farmers' perception. Perception will arise based on some factors affecting it, so that attention should be paid to the relationship between farmers and Babinsa. Weru Sub District of Sukoharjo Regency as the implementer of Upsus Pajale who has cooperated with Babinsa in each of village is very important to study to find out the farmers' perception on the role of Babinsa in Upsus Pajale. In addition, a study should be conducted on the factors affecting the farmers' perception on the role of Babinsa in Upsus Pajale in Weru Sub District of Sukoharjo Regency.

\section{Research Method}

This research employed quantitative research method, focusing on collecting numeric data to be analyzed later using quantitative analysis instrument and mathematic calculation. This method is intended to test the hypothesis formulated [7]. The research technique employed was survey technique, the technique of research taking sample from a population using questionnaire as an instrument of collecting data intended to explain the variables through 
hypothesis testing [8]. The research location was selected purposively based on the objective of research. The research took place in Weru Sub District of Sukoharjo Regency, Central Java, constituting the area implementing Upsus Pajale with three commodities: rice, corn, and soybean. Weru Sub District is also the one with highest productivity for those three commodities during 2015-2016. The research was conducted in 2 villages: Karangwuni (the village with farthest distance from Sub District City) and Tegalsari (the village with closest distance from Sub District City).

The population of research was farmers in Karangwuni Village consisting of 4 farmer groups: Marsuditani, Ngudi Sari, Suko Karyo, and Sido Mukti, and those in Tegalsari consisting of 6 farmers groups: Samekto, Serba Guna, Krido Usodo, Margo Utomo, Margo Bejo, and Budi Luhur, totally consisting of 902 farmers. The sampling in this study was conducted using simple random sampling technique, the technique of taking sample randomly from the members of population regardless the strata existing in the population [9]. The sample taken in this study consisted of 70 farmers. The types of data used were quantitative and qualitative data. Data sources used were primary and secondary data. Primary data was obtained directly from respondents, while secondary data was cited directly from government institution or institutions relevant to the study. Techniques of collecting data used were observation, interview, documentation, and recording. Data used was ordinal data with likert scale with the criterion of interval range presented in the formula below:

Interval range $=\left(\sum\right.$ highest score - Llowest score $):$ number of classes

Then analysis was conducted by calculating the sum of answer scores based on scoring of each respondent's answer to be represented on continuum line to find out its category. The scoring formula to represent continuum line is as follows:

Total Score $=($ total respondent answering SS x SS score $)+$

(total respondent answering $\mathrm{S} \times \mathrm{S}$ score) +

(total respondent answering $\mathrm{N} x \mathrm{~N}$ score) +

(total respondent answering TS x TS score) +

total respondent answering STS x STS score) (2)

Total ideal score (highest score/all respondents answer SS) $=70 \times 5=350$

Total ideal score (lowest score/all respondents answer STS) $=70 \times 1=70$

It can be represented in the continuum as follows

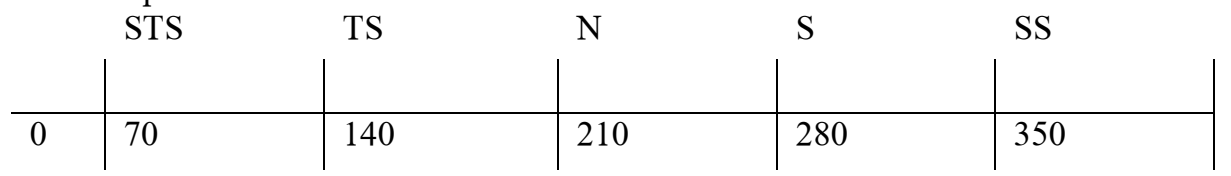

Notes: $\mathrm{STS}=$ Very disagree, TS: Disagree, $\mathrm{N}=$ Neutral, $\mathrm{S}=$ agree, $\mathrm{STS}=$ Very Agree

Analysis of the relationship between factors affecting perception and the farmers' perception on the role of Babinsa in Upsus Pajale was conducted using Spearman's rank correlation. Spearman's rank correlation formula [10], is as follows:

$\mathrm{rs}=1-\frac{6 \sum_{\mathrm{i}=1}^{\mathrm{N}} \mathrm{di}^{2}}{\mathrm{~N}^{3}-\mathrm{N}}$

Where:

rs = Spearman's Rank Correlation Coefficient

$\mathrm{N}=$ Number of Respondents

di = difference or ranking of observed variables

The criteria of test are: 
Ho is supported if sig. (2-tailed) $>\alpha$, meaning that there is no significant correlation between factors affecting perception and farmers' perception on the role of Babinsa in Upsus Pajale.

\section{Result and Discussion}

Weru Sub District is one of 12 sub districts existing in Sukoharjo Regency located at 118 meter altitude. Weru Sub District is about $20 \mathrm{~km}^{2}$ from Regency capital and consists of 13 villages. The number of population in Weru Sub District consists of 49,532 people: 29,434 people in productive age and 20,098 in non-productive age. The dependency ratio is 68.28 , meaning that each 100 productive age people assume the burden of 68 non-productive age people. Weru Sub District's area is $41.98 \mathrm{~km} 2$ wide, $51 \%$ of the width is used for rice farmland. Most of rice farmlands $(16.13 \mathrm{~km} 2)$ in Weru Sub District are technical watering system (technical irrigation, semi-technical irrigation, and simple irrigation), and $3.76 \mathrm{~km} 2$ are rainfed land [11]. Republic of Indonesia Minister of Agriculture's Regulation Number 14/Permentan/OT.140/3/2015 about integrated guarding and facilitation by Extension Officer, College Students, and Bintara Pembina Desa (Babinsa or Non-commissioned law enforcement officer) in the special attempt of improving rice, corn, and soybean production explains that Babinsa serves to help the extension officer particularly in implementing simultaneous movement, guarding, and pacification. In doing its task helping the extension officer, Babinsa serves as facilitator and is expected to give role model in the term of discipline applied to the farmers in their farming. J. Dwi Narwoko and Bagong Suyanto (2010) said that the role can guide an individual in behaving, because the function of role includes giving direction in the process of socialization; tradition inheritance, belief, values, norms and knowledge; can unite group or community, and rekindle controlling system, thereby can preserve the society life [12].

\subsection{Farmers' Perception on the role of Babinsa in Upsus Pajale}

Perception depends on such factors as personal, social-economic, socio-cultural, and socialpolitical parameters [13]. The factors affecting perception appropriateness are age, intelligence, complexity, cognitive, popularity, personal characteristics, and training impression or learning outcome [14]. Then, [15] suggest that an individual's characteristics will also affect perception, in which the perception in turn will affect an individual's behavior or action. Farmers' perception on the role of Babinsa in Upsus Pajale in Weru Sub District is farmers' perception on Babinsa's role in guiding the government's Upsus Pajale program running in Weru Sub District. The assessment includes farmers' perception on the role of Babinsa as motivator, facilitator, and supervisor. Farmers' perception in this research was classified into very poor, poor, fair/neutral, good, and very good categories. The role of Babinsa here is similar to the role of extension officer, including communicator, educator, motivator, innovator, and facilitator. Amalia Asdar et al. define perception as an active process of using mind (thinking) thereby evoking response to stimulus. Perception developing inside the farmers will affect their view on the role of extension officer. The farmers' perception on the role of extension officers can be one of supporting and inhibiting factors to the farmers' participation or involvement in extension activity. Perception, according [16] is the impression obtained by an individual through five senses to be analyzed (organized), interpreted, and evaluated later, so that the individual gets the meaning. 


\subsubsection{Farmers' Perception on the role of Babinsa as Motivator}

Farmers' high participation is an indicator of a successful program. Incentive or motivation is required to invite the farmers to accept the program planned or launched by government, either from inside famers or from others. In the Special Effort Program For Improving Rice, Corn, and Soybean or Upsus Pajale, corresponding to the Minister of Agriculture's Regulation, one of roles the Babinsa plays as the facilitator is to be motivator. The role of Babinsa as motivator is to activate and to motivate the farmer in the terms of simultaneous planting, irrigation, and Plant Pests control. Farmer's perception on the role of Babinsa as motivator in Weru Sub District can be seen in the table below.

Table 1. Distribution of Respondents by Perception on the Role of Motivator

\begin{tabular}{|l|r|r|r|r|}
\hline Category & $\begin{array}{c}\text { Range of } \\
\text { Interval }\end{array}$ & $\begin{array}{c}\text { Number of } \\
\text { Respondent }\end{array}$ & Total (\%) & Total score \\
\hline Very Poor & $17.0-30.6$ & 1 & 1.43 & 1 \\
\hline Poor & $30.7-44.3$ & 19 & 27.14 & 38 \\
\hline Fair/Neutral & $44.4-58.0$ & 37 & 52.86 & 111 \\
\hline Good & $58.1-71.7$ & 11 & 15.71 & 44 \\
\hline Very Good & $71.8-85.4$ & 2 & 2.86 & 10 \\
\hline Total & 70 & 100.00 & 204 \\
\hline Minimum Score & & & 70 \\
\hline Maximum Score & & & 350 \\
\hline Percentage (Total Score / Maximum score) & & $58.2 \%$ \\
\hline
\end{tabular}

Source: Primary Data Analysis, 2019

Considering the data shown in Table 1, it can be found the distribution of respondents by perception on the role of Babinsa as motivator. The data shown in Table indicates that $37(52.86 \%)$ respondents perceive that the role of Babinsa as motivator is fair (neutral), 19 (27.14\%) perceive it as poor, $11(15.71 \%)$ perceive it as good, $2(2.86 \%)$ perceive it as very good, and $1(1.43 \%)$ perceive it as very poor. On continuum it can be represented as follows.

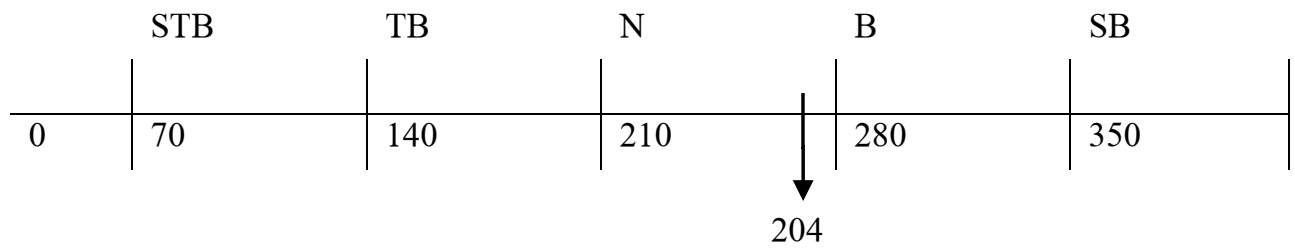

Notes: STB $=$ Very poor, TB, Poor, $\mathrm{N}=$ Neutral, $\mathrm{B}=$ Good, $\mathrm{SB}=$ Very Good

Fig. 1. Continuum Line of Perception on Motivator Role

The result above shows that majority respondents score fairly the role of Babinsa as the motivator, meaning that some of Babinsa's role as motivator has been implemented, but some other has not been yet, so that the farmers in Weru Sub District neither have accepted well nor decline the role of motivator in facilitating Upsus Pajale. Babinsa's role as motivator is, among others, to activate and to motivate the farmers to repair and to maintain irrigation network. Before the presence of Upsus Pajale, irrigation in Weru Sub District has been managed sufficiently well and utilized by farmers. Even in Tegalsari, when the water volume has been reduced or around dry season, they can utilize water from Gajah Mungkur reservoir of Wonogiri Regency, so that most farmers in this village can plant rice in three planting period. 


\subsubsection{Farmers' Perception on the role of Babinsa as Facilitator}

Farmers' perception on Babinsa's role as facilitator in this research is farmers' assessment on the role of Babinsa in implementing support in certain or urgent condition related to the distribution of fertilizer, seed, and agricultural machinery, and irrigation network infrastructure. Farmers' perception on the role of Babinsa as facilitator in Weru Sub District can be seen from the table below.

Table 2. Distribution of Respondents by Perception on the role of facilitator

\begin{tabular}{|l|l|l|l|l|}
\hline Category & $\begin{array}{c}\text { Range of } \\
\text { Interval }\end{array}$ & $\begin{array}{c}\text { Number of } \\
\text { Respondents }\end{array}$ & Total (\%) & Total Score \\
\hline Very Poor & $21-37.8$ & 0 & 0 & 0 \\
\hline Poor & $37.9-54.7$ & 29 & 41.43 & 58 \\
\hline Fair/Neutral & $54.8-71.6$ & 22 & 31.43 & 66 \\
\hline Good & $71.7-88.5$ & 17 & 24.28 & 68 \\
\hline Very Good & $88.6-105.4$ & 2 & 2.86 & 10 \\
\hline Total & 70 & 100.00 & 202 \\
\hline Minimum Score & & & 70 \\
\hline Maximum Score & & & 350 \\
\hline Percentage (Total Score / Maximum score) & & $57.7 \%$ \\
\hline
\end{tabular}

Source: Primary Data Analysis, 2019

Data shown in table 2 indicates that $29(41.43 \%)$ respondents perceive poorly the role of Babinsa as facilitator, $22(31.43 \%)$ perceive it fairly, $17(24.28 \%)$ perceive it well, and 2 $(2.86 \%)$ perceive it very well. It in can be represented on the continuum line below.

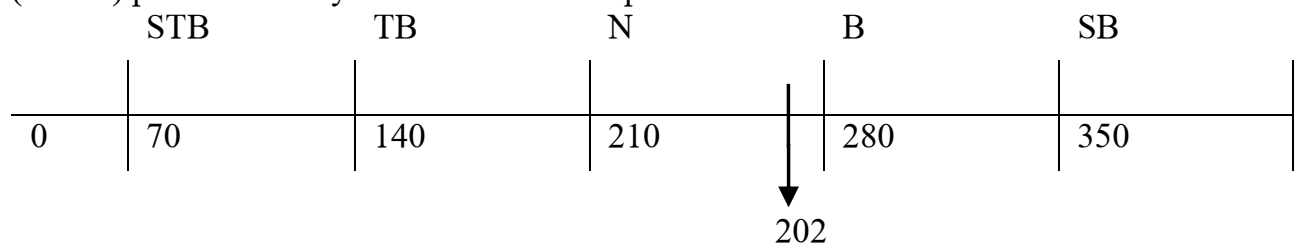

Fig. 2. Continuum Line of Perception on the role of Facilitator

Most farmers have poor perception on the role of Babinsa as facilitator, meaning that Babinsa have not implemented its role well as the facilitator in Upsus Pajale, despite some (17) respondents or $24.28 \%$ perceive it as good. The 17 respondents perceive the Babinsa's role well are those who know that Babinsa is assigned to facilitate the implementation of Upsus Pajale and most of them are administrators of individual farmer groups affiliated in Gapoktan (Farmer Group Association) holding routine meeting often involving Babinsa.

\subsubsection{Farmers' perception on the role of Babinsa as Supervisor}

Farmers' perception on Babinsa's role as supervisor is farmers' assessment on the role of Babinsa in conducting supervision. Supervision that should be conducted by Babinsa is firstly that over administration filing and distribution of grant to beneficiary. Secondly, it is related to identification activity, registration, and technical reporting on the activity implementation. Farmers' perception on the role of Babinsa as supervisor in Weru Sub District can be seen in the table below. 
Table 3. Distribution of Respondents by Perception on the Role of Supervisor

\begin{tabular}{|l|l|l|l|l|}
\hline Category & $\begin{array}{c}\text { Range of } \\
\text { Interval }\end{array}$ & $\begin{array}{c}\text { Number of } \\
\text { Respondents }\end{array}$ & Total (\%) & Total Score \\
\hline Very Poor & $5-9$ & 12 & 17.14 & 12 \\
\hline Poor & $10-14$ & 40 & 57.14 & 80 \\
\hline Fair/Neutral & $15-19$ & 11 & 15.72 & 33 \\
\hline Good & $20-24$ & 7 & 10.00 & 28 \\
\hline Very Good & $25-29$ & 0 & 0 & 0 \\
\hline Total & 70 & 100.00 & 153 \\
\hline Minimum Score & & & 70 \\
\hline Maximum Score & & & 350 \\
\hline Percentage (Total Score / Maximum score) & & \\
\hline
\end{tabular}

Source: Primary Data Analysis, 2019

Data shown in Table 3 indicates that 40 (57.14\%) respondents perceive poorly the role of Babinsa as supervisor, $12(17.14 \%)$ perceive it very poorly, $11(15.72 \%)$ perceive it fairly, and $7(10.00 \%)$ perceive it very well. It can be represented on the continuum below:

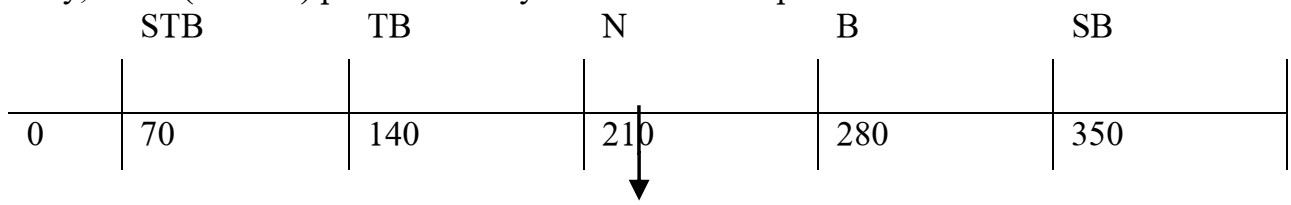

Fig. 3. Continuum Line of Perception on the role of Supervisor

More than a half of respondents have poor perception on the role of Babinsa as supervisor, farmers view Babinsa having not implemented its role optimally yet as supervisor. However, 7 respondents $(10.00 \%)$ perceive well the role of Babinsa as supervisor. It occurs in the farmer group with active Babinsa (6 respondents) and 1 respondents in farmer group with less active Babinsa. Thus, it can be said that respondents cannot feel the benefit of Babinsa's role as supervisor because Babinsa performs its role less actively.

\subsubsection{Farmers' Perception on the Role of Babinsa}

Farmers' perception on the role of Babinsa measured entirely including the roles of motivator, facilitator, and supervisor. Farmers' perception on Babinsa's role can be seen in table 4.

Table 4. Distribution of Respondents by Perception on the Role of Babinsa

\begin{tabular}{lllll}
\hline Category & Range of Interval & $\begin{array}{l}\text { Number of } \\
\text { Respondents }\end{array}$ & Total (\%) & Total Score \\
\hline Very Poor & $43-77,4$ & 0 & 0 & 0 \\
Poor & $77,5-119,9$ & 34 & 48,6 & 68 \\
Fair/Neutral & $120-154,4$ & 29 & 41,4 & 87 \\
Good & $154,5-188,9$ & 5 & 7,1 & 20 \\
Very Good & $189-223,4$ & 2 & 2,9 & 10 \\
\hline Total & 70 & 100.00 & 185 \\
\hline Minimum Score & & & 70 \\
Maximum Score & & & 350 \\
Percentage (Total Score / Maximum score) & & &
\end{tabular}


Data shown in Table 4 indicates that 34 (48.6\%) respondents perceive poorly the role of Babinsa, 29 (41.4\%) perceive it fairly, 5 (7.1\%) perceive it well, and $2(2.9 \%)$ perceive it very poorly. It can be represented on the continuum below.

\begin{tabular}{|c|c|c|c|c|c|}
\hline & STB & TB & $\mathrm{N}$ & B & SB \\
\hline 0 & 70 & 140 & 210 & 280 & 350 \\
\hline
\end{tabular}

Fig. 4. Continuum Line of Perception on the role

The measurement using the range of interval shows that the farmers' perception on the role of Babinsa is poor (not good). However, using continuum line, farmers' perception on Babinsa's role belongs to fair category. It indicates that farmers' perception on Babinsa's role belong to moderate (fair) category. Most farmers are still in fair category, meaning that they are still skeptic with the role of Babinsa. It because Babinsa still perform its role less actively and less optimally, so that many farmers have not benefited from the existence of Babinsa. It may occur due to different understanding between one farmer and another. According to [17], it is inseparable from individual's characteristics and other factors affecting individual farmers' process of receiving information.

\subsection{The relationship between factors affecting Farmers' Perception and Farmers' Perception on the role of Babinsa}

The analysis was used to find out the relationship between factors affecting farmers' perception on Babinsa's role in Upsus Pajale using Spearman's Rank Correlation with SPSS version 20 for windows program help. To find out the significance level by comparing the sig. (2-tailed) and $\alpha$ value at confidence interval of $95 \%(\alpha=0,05)$. When sig. (2-tailed) $\leq \alpha, \mathrm{H} 0$ is not supported, meaning that there is no significant relationship between factors affecting farmers' perception and farmers perception on the role of Babinsa in Upsus Pajale in Weru Sub District of Sukoharjo Regency. Otherwise, when sig. (2tailed) $>\alpha, \mathrm{H} 0$ is supported, meaning that there is a significant relationship between factors affecting farmers' perception and farmers perception on the role of Babinsa in Upsus Pajale in Weru Sub District of Sukoharjo Regency. The result of analysis of the relationship between factors affecting farmers' perception and farmers' perception on the role of Babinsa in Upsus Pajale can be seen in the table below.

Table 5. Spearman's Rank test on the relationship between Factors affecting farmers' perception and farmers' perception on the role of Babinsa in Upsus Pajale in Weru Sub District of Sukoharjo Regency

\begin{tabular}{llllllllll}
\hline & \multicolumn{2}{l}{ Motivator Role (Y1) } & $\begin{array}{l}\text { Facilitator } \\
\text { (Y2) }\end{array}$ & Role & $\begin{array}{l}\text { Supervisor } \\
\text { (Y3) }\end{array}$ & Role & $\begin{array}{l}\text { Total } \\
\text { (Ytot) }\end{array}$ & Perception \\
\cline { 2 - 9 } & rs & $\begin{array}{l}\text { Sig. } \\
\text { tailed) }\end{array}$ & rs & $\begin{array}{l}\text { Sig. (2- } \\
\text { tailed) }\end{array}$ & rs & $\begin{array}{l}\text { Sig. (2- } \\
\text { tailed) }\end{array}$ & rs & $\begin{array}{l}\text { Sig. (2- } \\
\text { tailed) }\end{array}$ \\
\cline { 2 - 9 } & & $0.417^{* *}$ & 0.000 & $0.454^{* *}$ & 0.000 & 0.194 & 0.108 & $0.523^{* *}$ & 0.000 \\
$\mathrm{X} 2$ & $0.660^{* *}$ & 0.000 & $0.436^{* *}$ & 0.000 & $0.243^{*}$ & 0.043 & $0.601^{* *}$ & 0.000 \\
$\mathrm{X} 3$ & $0.455^{* *}$ & 0.000 & $0.482^{* *}$ & 0.000 & 0.086 & 0.477 & $0.584^{* *}$ & 0.000 \\
$\mathrm{X} 4$ & $0.303^{*}$ & 0.011 & $0.510^{* *}$ & 0.000 & 0.014 & 0.906 & $0.496^{* *}$ & 0.000 \\
\hline
\end{tabular}

Source: Primary Data Analysis, 2019 


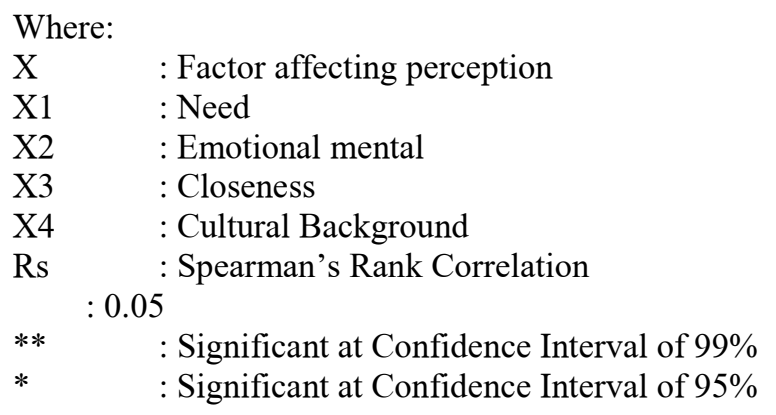

\subsubsection{The Correlation between need and farmers' perception on the role of Babinsa in Upsus Pajale}

From table 5, it can be seen rs value of 0.523 at sig. (2-tailed) $0.000 \leq \alpha, 0.05$; therefore $\mathrm{H} 0$ is not supported. It means that there is a very significant relationship between need and farmers' perception on the role of Babinsa in Upsus Pajale in Weru Sub District of Sukoharjo Regency at confidence interval of $95 \%$. The need in this study is related to the implementation of program corresponding to farmers' need for the role of Babinsa and Upsus Pajale.

This very significant relationship may occur due to respondents with the need corresponding to Upsus Pajale Program, therefore tend to interact more frequently with Babinsa. Thus, during program implementation, respondents more frequently need Babinsa to acquire supporting information. Considering this, it can be stated that the more the farmers' need corresponding to the role of Babinsa, the better will be the farmers' perception on the role of Babinsa.

\subsubsection{The Correlation between Emotional Mental and farmers' perception on the role of Babinsa in Upsus Pajale}

From table 5, it can be seen rs value of 0.601 at sig. (2-tailed) $0.000 \leq \alpha, 0.05$; therefore $\mathrm{H} 0$ is not supported. It means that there is a very significant relationship between emotional mental and farmers' perception on the role of Babinsa in Upsus Pajale in Weru Sub District of Sukoharjo Regency at confidence interval of 95\%. Farmers' emotion or feeling liking the role of Babinsa can affect their perception on the role of Babinsa. This very significant relationship may occur because the respondents liking much the role of Babinsa will respond to positively or have good perception on Babinsa. Meanwhile, the farmers not liking the role of Babinsa may respond to less positively and such response can generate less good (poor) perception on the role of Babinsa. Considering the result of field work, the author will like Babinsa who perform its role according to the enacted regulation. However, in fact, out of many roles only some are performed by Babinsa, so that farmers do not like it too much and it generates the farmers' poor perception on the role of Babinsa.

\subsubsection{Correlation between closeness and farmers' perception on the role of Babinsa in Upsus Pajale}

From table 5, it can be seen rs value of 0.584 at sig. (2-tailed) $0.000 \leq \alpha, 0.05$; therefore $\mathrm{H} 0$ is not supported. It means that there is a very significant relationship between closeness and farmers' perception on the role of Babinsa in Upsus Pajale in Weru Sub District of Sukoharjo Regency at confidence interval of $95 \%$. Closeness the farmers have to Babinsa 
will be varying between one farmer and another. Farmers having closeness to Babinsa, e.g. seeing each other more frequently and interacting positively such as discussing or consulting with each other concerning Upsus Pajale, tend to respond well to the role of Babinsa in Upsus Pajale. Meanwhile, the farmers having closeness to Babinsa, even in this case many farmers have never seen Babinsa, respond poorly to the role of Babinsa. In relation to the duty of Babinsa as mentioned in Minister of Agriculture's Regulation Number 14 of 2015, farmers will respond positively to the duty. However, in fact, because its implementation is less consistent with the Law, many farmers have no closeness to Babinsa. Thus, they respond less positively to the role of Babinsa in Upsus Pajale.

\subsubsection{Correlation between cultural background and farmers' perception on the role of Babinsa in Upsus Pajale}

From table 5, it can be seen rs value of 0.496 at sig. (2-tailed) $0.000 \leq \alpha, 0.05$; therefore $\mathrm{H} 0$ is not supported. It means that there is a very significant relationship between cultural background and farmers' perception on the role of Babinsa in Upsus Pajale in Weru Sub District of Sukoharjo Regency at confidence interval of 95\%. Culture observed in this study is farmers' habit. One of it is farmers' bad habit. It can affect farmers' perception on the role of farmers. For example, in relation to the farmers' bad habit, when farmers is facilitated by Babinsa, they cannot do their habit of breaking the rule discretionarily, one of which is to steal water. Such condition results in varying perceptions among the farmers, between the farmers breaking and those not breaking the rule.

This research indicates that farmers' perception on the roles of Babinsa in Upsus Pajale in Weru Sub District of Sukoharjo Regency including motivator, facilitator, and supervisor belong to fair/neutral category. There is a very significant relationship between factors affecting perception - need, emotional mental, closeness, and cultural background - and farmers' perception on the role of Babinsa in Upsus Pajale. This research contributes to Upsus Pajale Program to study its policy further, in which the role of Babinsa have not benefited the farmers completely, so that the farmers still have fair/neutral perception on Babinsa's role. Government, particularly the ministry of agriculture, should pay more attention to the borders of Babinsa and agricultural extension officer's roles because considering the result of research, some of Babinsa's roles have been performed by the extension officer.

\section{Conclusion}

This study shows that farmers' perceptions of the role of Babinsa in Upsus Pajale in Weru District, Sukoharjo Regency which include roles as motivators, facilitators, and supervisors are in the medium / neutral category. There is a very significant relationship between the factors that influence perceptions, namely needs, mental emotionality, closeness, and cultural background with farmers' perceptions of the role of Babinsa in Upsus Pajale. This research contributes to the Upsus Pajale program to further examine its policy, that the role of Babinsa has not been fully felt by farmers so that farmers' perceptions of the role of Babinsa are still moderate / neutral. For the government, especially the ministry of agriculture, it is necessary to pay more attention to the role boundaries between Babinsa and extension workers because based on the results of the research it was found that some of the roles of Babinsa were carried out by extension workers. 


\section{References}

1. A. Anwari. Kondisi Ketahanan Pangan Indonesia Saat Ini. https://www.kompasiana.com/akbaranwari/kondisi-ketahanan-pangan-indonesia-saatini_54f74afda33311e32b8b4567. accessed on April 23, 2018 (2015)

2. Ponto, Jeremy, Noortje M Benu, dan Ribka M Kumaat. Upsus Pajale dalam Menunjang Program Swasembada Pangan di Kabupaten Bolaang Mongondow. Jurnal Agri-Sosio Ekonomi Unsrat Volume 13 (2A): 253 - 260 (2017)

3. Wahyudin, Ade Rohmad. Peranan Bintara Pembina Desa (Babinsa) dalam Menunjang Ketertiban dan Keamanan Masyarakat di Desa Warembungan Kecamatan Pineleng Kabupaten Minahasa. Jurnal Governance 5:53-64 (2013)

4. Solih. Peran Babinsa dalam Swasembada Pangan. http://www.tni.mil.id/view-112024peran-babinsa-dalam-swasembada-pangan.html. Accessed on April 23, 2018 (2017)

5. Van den Ban, A.W., Hawkins, H.S. Penyuluhan Pertanian. Yogyakarta: Penerbit Kanisius (1999)

6. Soerjono Soekamto. Teori Peranan. Jakarta : Bumi Aksara (2002)

7. Sugiyono. Metode Penelitian Kuantitatif Kualitatif dan R\&D. Bandung: Alfabeta (2012)

8. M. Singarimbun, dan S. Efendi. Metode Penelitian Survey. Jakarta: Media Pratama (1986)

9. T. Mardikanto. Prosedur Penelitian untuk Kegiatan Penyuluhan Pembangunan dan Pemberdayaan Masyarakat. Surakarta: Prima Theresia Presindo (2006)

10. S. Siegel. Statistika Non Parametrik untuk Ilmu-ilmuSosial. Jakarta: PT Gramedia (1997)

11. Badan Pusat Statistik Sukoharjo. Kecamatan Weru dalam Angka 2018. BPS Kabupaten Sukoharjo (2018)

12. Kementerian Pertanian. Peraturan Menteri Pertanian Nomor 03/Permentan/0T.140/2/2015.Republik Indonesia: Kementerian Pertanian (2015)

13. Clark R.C and Akinbode I.A. Factors Associated with adoption of three farm practices in Western states of Nigeria. Research Bulletin (1), Faculty of Agriculture, University of Ife, Ile - Ife (1986)

14. Devito, J.A. Komunikasi Antar Manusia. Jakarta: Edisi ke Lima. Terjemahan Profesional Books. (1997)

15. Rogers, E.M., and F.F. Shoemaker. Communication of Innovations: A Cross Cultural Approach. New York: Tha Free Press (1971)

16. Robbins, Stephen P,. Perilaku Organisasi, Jilid 2. Jakarta : Gramedia (2003)

17. Devito, J.A. Komunikasi Antar Manusia. Jakarta: Edisi ke Lima. Terjemahan Profesional Books. (1997) 